\title{
Hoabinhian and Austronesia: The Root of Diversity in the Western Part of Indonesia
}

\author{
Dr. Ketut Wiradnyana., M.Si \\ Archaeological Research Office of Northern Sumatera, Indonesia
}

doi: 10.19044/esj.2016.v12n32p131 URL:http://dx.doi.org/10.19044/esj.2016.v12n32p131

\begin{abstract}
The western part of Indonesia mentioned in this paper includes the provinces of North Sumatera and Aceh, in the northern part of Sumatera. The two provinces are rich in archaeological remains, particularly those from Early Holocene up to the megalithic culture. Human activities during the Early Holocene were characterized by the presence of Kitchen Midden sites and Austromelanesoids with Hoabinh culture. This culture is commonly found along the east coast of the two provinces, and some of them are on highlands. The Neolithic culture, which contributes highly significant Austronesian data, are found at the sites on highland area, while other cultures from later period contribute the Megalithic culture that continues until now and becomes the living tradition. The entire depiction is the achievement from a series of archaeological researches, which in turn describes the mixing process among humans and their cultures. The result is a diversity of Indonesian people, particularly in the western part of Indonesia.
\end{abstract}

Keywords: Diversity, hoabinhian, austronesia

\section{Introduction}

Diversity among Indonesian people has occurred since the prehistoric period. The presence of ethnic groups in every cultural area was the result of admixture processes, which was accompanied with cultural intermingling. It was also the case in the western part of Indonesia, which is now the home of various ethnic groups. Undoubtedly race mixture is not as intensive as cultural mixture, due to the fact that race existence is more limited than the existence of ethnic cultural entities. Based on that fact, there are two important aspects that underlie the diversity in the western part of Indonesia, which are inter-racial mixture, together with cultural mixture, and cultural mixture within the same race. It is shown by the admixture of the Australomelanesoids and the Mongoloids and their cultural items. In later 
period there was also an admixture with the Mongoloids and its Austronesian culture. So the existence of the ethnic groups in the western part of Indonesia is resulted from the admixture of various groups of people and their cultures, which was a process that took a very long period of time.

Until now the existence of early human populations in west Indonesia has only been known owing to the discoveries of human skeletons and remains of their material culture, which are identified as the Australomelanesoids and Hoabinh culture. They were not only found along the east coast of Sumatera, but also on highland areas. Therefore traces of diversity in west Indonesia has not been known until the Early Holocene period, which was the activity period of their populations. The Hoabinh culture that flourished during that period was the foundation of the next period's culture.

The presence of Hoabinhian (hoabinh culture) sites along the coast, which are in the forms of kitchen middens, as well as those on highland areas that are located in caves and rock shelters, are the main data of this article. Likewise are the sites from later period (the Neolithic). Those sites include Bukit Kerang Pangkalan in Aceh Tamiang Regency and Loyang Mendale in Aceh Tengah in Regency. Both are within the Province of Aceh. Regarding the occupational process in west Indonesia until the post-Neolithic period, the data were obtained from the megalithic sites of Nias and Samosir islands.

\section{Early Holocene in West Indonesia}

Activities during the Early Holocene period in northern coast Sumtra were characterized by the presence of distinctive Hoabinh culture, which refers to a stone tool industry marked by mono-facial and bifacial pebble tools. Frequently the entire sides become the sharp edge. The flaking shows various shapes. At Hoabinhian sites such stone tools were found together with flakes, mortars and pestles in various sizes, bone spatulas and points, as well as human remains buried in flexed position and sprinkled with hematite.

The Hoabinh culture is distributed throughout Southeast Asia, southern China, and Southeast, Taiwan. Thus far all the sites that have been dated using Radio-carbon method reveal a period of 18,000 to 3,000 years ago (Bellwood,2000:238-241). The Southeast areas includeVietnam, Laos, Cambodia, Thailand, Malaysia and Indonesia. There is an assumption that this culture was originated from southern China and has developed since the Pleistocene period until the Pre Neolithic period, or about 5,000 BP. In Indonesia, the distribution of the Hoabinh culture is indicated to be through the Malay Peninsula (Soejono \& Leirissa, 2009:175-176), but there is a possibility that it came from other places such as Thailand. Result of dating on specimen from Ongbah Cave site in Thailand that reveals a date of 8,810 $\pm 170 \mathrm{BP}$, which is within the same age with the Hoabinhian sites in 
Indonesia, is one of the indicators. The bearers of the Hoabinh culture commonly practiced hunting and gathering food at coastal and inland areas, and Hoabinhian remains tend to be found at sites from a period before pottery was known.

The locations where the Hoabinh cultures were found in Sumatera can be divided into two types, namely coastal Hoabinhian sites and highland Hoabinhian sites. But generally they are located along the east coast of Sumatera. The presence of Hoabinhian sites in mountainous (highland) area shows the extent of dispersal area of their bearers, and that some of the populations lived in mountainous area.

The site of Bukit Kerang Pangkalan (Pangkalan Shell Midden) is one of the coastal Hoabinhian sites in Aceh Province, which is located about 20 $\mathrm{km}$ from recent coastline and about $1.5 \mathrm{~km}$ from the Tamiang River. The Pangkalan Shell Midden site has three cultural layers. The lowest layer is dated from 12,550 $\pm 290 \mathrm{BP}$, and there are charcoal (remain of burning activities) and hand-axes, technology and morphology look like from the Paleolithic period. There are to make assumptions about the end of the Paleolithic or early Mesolithic, or distinctive technologies that Mesolitik period. The middle cultural layer, which has Hoabinhian characteristic, is from Early Holocene period and is dated from 5,100 \pm 130 BP to 4,460 \pm 140 BP. In this layer was found various stone tools with Hoabinhian morphology and technology, as well as flexed burial. The topmost layer is Neolithic, among others fragments of pottery from around 3,870 $\pm 140 \mathrm{BP}$ and short axes with polished sharpening edge.

Other lowland Hoabinhian sites in North Sumatera and Aceh indicate that there are fragments of pottery at the upper part. Pottery has never been found at the mid-depth of the sites.

Highland Hoabinhian sites are also found at Gua Kampret (Bat Cave) Site in the regency of Langkat, North Sumatera Province. On the hollow dirt wall outcrop fragments of pottery were found and at deeper part were found pebble tools with morphologically belong to Early Holocene period and Hoabinhian characteristics (Wiradnyana,2011:29). The presence of pottery on site surface also indicates similar condition to the coastal Hoabinhian sites.

Loyang Mendale is one of the prehistoric sites on highland area with Hoabinhian and Austronesian characteristics. It is located by the bank of Lut Tawar Lake in Aceh Tengah (Central Aceh) Regency. The finds of this site, which is actually a rock shelter, strongly indicate Early Holocene-Neolithic phase. The lowest layer yielded sumatraliths, stone flakes, and mollusks' shells. The dating of this Early Holocene layer is 8,430 $\pm 80 \mathrm{BP}$ to 5,040 \pm 130 BP (Wiradnyana et al, 2015:79). The morphology of the lithic tools found at Loyang Mendale Site is similar to those found at coastal 
Hoabinhian sites. Lithic tools from Hoabinhian sites in Indonesia and Southeast Asia are often classified into Early Holocene technology group.

\section{The Neolithic of Loyang Mendale Site}

By Austronesian Culture here we mean that a site dominated by various artifacts with Austronesian cultural characteristics (Neolithic). Austronesia is a terminology that refers to a family of language, but in its development it also refers to the speakers and culture. Scholars tend to believe that this culture is originated from Taiwan due to the fact that the earliest archaeological finds and settlements that bear the Austronesian characteristics are dated from between 4,000 and 3,000 years BC. Furthermore, vocabulary for pottery as one of cultural items was found among the early Malayu-Polynesian people in Taiwan at about that period, which means that Austronesian cultural characteristics and language have been found in Taiwan 1,000 years before it existed in Kalimantan (Borneo) and Sulawesi (Celebes) through quite fast migrations just before 2,000 BC (Bellwood, 2000:161-174).

Archaeology relates the Austronesian culture to the phasing of Neolithic culture (Simanjuntak,2016:3). The material remains that are frequently used as the basis of the Austronesian culture include among others polished stone tools (quadrangular adzes and elongated/ovoid axes), agriculture, animal domestication (particularly dogs and pigs), stilt houses, and pottery. The next phase is characterized by the use of metal (iron and bronze). Agriculture, which was practiced by the bearers of this culture have been carried out with a good system. Several kinds of tubers, as well as rice, were planted. The use of a system in the agricultural sector shows that there has been a sedentary and better organized life compared to the earlier period.

Austronesian sites on the northern part of Sumatera are: Loyang Mendale, Loyang Ujung Karang, and Putri Pukes. At the three sites there are strong indications of flourished Austronesian culture, which is not merely characterized by polished rectangular adzes and elongated/ovoid axes, and flake tools, but also human remains in flexed position. Other finds include fragments of pottery, beads made of bones and mollusks' shells, and fragments of container made of woven rattan.

At the site of Loyang Mendale, above the Hoabinhian layer, were found a number of polished stone tools in forms of rectangular adzes and elongated/ovoid axes, as well as other finds like holed canine tooth, human skeletons, and fragments of pottery. The oldest Neolithic layers are dated, using bone samples, to 4,980 $\pm 130 \mathrm{BP}$ and 3,580 $\pm 100 \mathrm{BP}$ (cal. 2,087$1,799 \mathrm{BC}$ ) and also 1,740 $\pm 100 \mathrm{BP}$ (210 AD) (Wiradnyana and Taufiqurrahman,2011:111). The discussion reveals that there are two cultural layers at Loyang Mendale Site, which are the Hoabinhian and Austronesian 
layers. At Loyang Ujung Karang Site, dating using sample from burnt ashes reveals a date of 5,080 $\pm 120 \mathrm{BP}$, and other ones using samples of ashes and mollusk's shell yield a date of 4,940 \pm 120 BP. As for the oldest Austronesian culture or last Hoabinh with a context with the flexed burial at Loyang Ujung Karang Site, the date - which used bone sample - is 4,400 BP (cal.3,285-2,937 BC). This site also bears indication that during the same period when a group of people that bore Hoabinh culture carried out their activities at Loyang Mendale, a group of Austronesian speaking people also carried out their activities at Loyang Ujung Karang.

\section{Megalithic on the Islands of Nias and Samosir}

The Megalithic culture of Samosir Island, North Sumatera, is one of the evidences of proto-historic migration of the Austronesian speakers that brought with them this unique type of culture. Some burial containers known among the Batak Toba communities or those in the surrounding areas also have similar shapes, such as sarcophagi, and stone cists. On Samosir Island, burial in stone vats is also practiced by the Batak Toba people. The tradition to use stone vats as burial containers, based on the discoveries of various types of bronze objects at various sites in Indonesia is often associated with the characteristics of Dong Son Culture. In the island of Sumatera there is an indication that urn burial was widely practiced after the first millennium AD. Urn burials at Lolo Gedang in the Regency of Kerinci, Jambi, and at other sites around the area are dated to about $11^{\text {th }}-14^{\text {th }}$ centuries AD (Bonatz et al, 2006:500-502 in Budisantosa,2011:89-90). Secondary burial is still practiced by Batak Toba people and other ethnic communities in the surrounding area until now. It is carried out after the primary burial. In fact, in its development both primary and secondary burials are still practiced up to now.

On Nias Island, Early Holocene artifacts found during the archaeological excavation at Togi Ndrawa Cave reveal a date of 12,170 \pm $400 \mathrm{BP}$ up to $850 \pm 90 \mathrm{BP}$. This condition shows that there were settlements in the cave until after early first millennium AD. Development of result of radio-carbon analyses on Megalithic sites in the southern part of Nias reveals that at Boronadu, there were human activities in $576 \pm 30 \mathrm{BP}$, which is about 600 years ago, while at Tundrumbaho the activities occurred in about 340 $\pm 120 \mathrm{BP}$ or about 460 - 220 years BP and at Hili Gowe the date is $260 \pm 120$ $\mathrm{BP}$, or around 380 - 140 years ago (Wiradnyana,2010:25, 113). Those facts are evidences that the migration with the Megalithic tradition on Nias took place in around $14^{\text {th }}$ century AD. The Megalithic culture of Nias - generally known as gowe- which usually means megalithic structure, consists of standing and/or horizontally laid structures that were built during owasa ceremonies (processions to elevate social status). Some gowes are 
anthropomorphic megalithic statues while some others are natural (unworked) stones.

\section{Human and Culture Admixture in the Western Part of Indonesia Dating}

Indication that there were race admixtures is evidenced by the discovery of the oldest human skeletons, which are assumed to be of South Mongoloid direct lineage and date back to 20,000 years BP. The four skeletons were from a limestone rock shelter at Minatogawa in Okinawa Island (Suzuki and Hanihara,1982;Baba and Narasaki,1991). In the southern part of Mainland China, several Late Pleistocene skulls from Liujiang in Guangxi and Ziyang in Sichuan also indicate that there were race admixtures.Wu Xinzhi (1996) dated the Ziyang skulls to 35,000 BP, while Coon (1962:469) depicts the Liujiang ones as Mongoloids with some Australomelanesoid characteristics. Mixture of Mongoloid race is also shown by the Wajak men from East Java found in 1888 and 1890. Two individuals, which based on the femurs date back to about 6,500 BP, are thought by many scholars to be Australomelanesoids with big brain volumes and broad faces. But Coon (1962) and Jacob (1967) noted Mongoloid characteristic in their flat faces. Race admixture is also noted in the flexed burial in Niah Cave, Sarawak from 14,000 BP, which is one of the evidences of the evolution of Australoid/Australomelanesoid (Bellwood,2000:120125).

The above description shows that the Australomelanesoids have come to Southeast Asia earlier than the bearers of the Austronesian culture.In the western part of Indonesia, the earliest presence of the Australomelanesoids is around 12,000 BP.The race, which is the result of a mixture between Australoid with Melanesoid, can be found at Hoabinhian sites (Boedhisampurna,1983), while remains of the Mongoloids are found at Austronesian sites. Results of dating analyses on Austromelanesoid remains at shell midden sites tend to be older than those carried out on human remains from the Austronesian sites. Therefore it can be concluded that the shell midden sites, which belong to the cultural period of Early Holocene and with the Austromelanesoids as the bearers, are older than the Neolithic sites with the Mongoloids as the bearers.

This condition is not merely related to results of dating analyses, but more to aspects of culture, particularly subsistence, technology, and religion. Regarding the dates, the Hoabinhian sites are mostly dated from around 10,000 BP like at the sites of Moh Khiew Cave on the west coast of Southern Thailand (Pookajorn,996:347);Gua Runtuh (Runtuh Cave), Perak, Malaysia (Saidin,2012:17); as well as the sites along the east coast of Sumatera. Austronesian sites. The Austronesian sites are usually date back to 
after 5,000 BP, like those at Gua Cha (Cha Cave), Malaysia (around 3,700 \pm 250); Lue and Bang, Ban Kao, Thailand (around 3,720 $\pm 140 \mathrm{BP}$ ), and Moh Khiew Cave (3,300 BP in the Neolithic cultural layer) (Adi,1985; Sorensen,1967; in Pookajorn,1996:347).

From the culture (tecnology and ornament model) and analysis mitochondrial DNA (discussion with Prof. Herawati Sudoyo.,Ph.D,2016) The activities of the early Austronesian speakers at Loyang Mendale site began in around 4,980 $\pm 130 \mathrm{BP}$ dan 3,580 $\pm 100 \mathrm{BP}$ (cal. 2,087-1,799 $\mathrm{BC}$ ), and at di situs Loyang Ujung Karang in 5,080 \pm 120 BP, 4,940 \pm 120 BP.The date of Loyang Ujung Karang site in context with flexed burial is 4,400 BP. (cal.3,285-2,937 BC). (Wiradnyana and Taufiqurrahman,2011:111). During the previous period the bearers of the Hoabinh culture had lived at Loyang Mendale in 8,430 \pm 80 BP to 5,040 \pm 130 BP (Wiradnyana et al,2015:79). In that relation, it seems like the area had been occupied by two different races, namely Australomelanesoid and Mongoloid. Radio-carbon analyses indicate that both races lived together in the same period, or at least they lived in the same period although at two different caves. Based on their cultures, which both bear Neolithic characteristics, it can be assumed that they mingled together.

\section{Utilization the Same Occupation Locations}

A site's life-span for several periods in a region indicates a utilization of a migration route that tends to be the same from time to time. For example the utilization of the banks of Wampu River in North Sumatera and Tamiang River in Aceh as migration routes from Early Holocene (Hoabinhian), Neolithic (Austronesian), up to the Classical and Colonial periods, and even until now.In line with the use of the same migration routes, it is also the case with cultural phasing. Therefore the same migration routes can be regarded as "the silk route" of the past.

The mode of using the same occupation location can also be seen at the site of Gua Golo on Gebe Island, Central Halmahera, which shows four phases of human occupation based on the presence of four cultural layers. In the first cultural layer, which has a date of 3,500 BP (ANU 9448), are found among others fragments of pottery, animal bones, mollusks' shells, and 15 adzes made of shells (Cassis).The second layer consists of quite plenty mollusk' shells, bone points, and stone flakes from 7,500 BP (ANU 9449). In the third layer there is an adult human skeleton with plenty of ochre around it, and in the fourth layer was found adzes made of Tridacna that are assumed to be from 13,000-10,000 BP (Bellwood, 1996:8-9 in Soegondho,2008:96).

Moh Khiew Cave had also been occupied for five cultural phases. The first and second layers are Palaeolithic layers with a date of around 
37,000 BP. The third layer is similar to the Hoabinh cultural layer from around 10.000 BP.The fourth and fifth layers are Neolithic layers from 6.000 to 3,300 BP (Pookajorn,1996:342-247).The site with both Hoabinh and Neolithic cultural phases can also be found at the sites along the east coast of Sumatera Island from Holocene and Neolithic periods. At the shell midden site of Pangkalan, the oldest phase has a date of 12.550 BP while the last cultural layer, which is a Neolithic layer, dates back to around 3,870 BP. The presence of sites with several cultural layers shows that there were migrations at one site at different cultural phases. Each group had different influence on the previously settled group(s).The Hoabinhian group that came earlier around Loyang Mendale, for instance, had contact with the early Austronesian migrated group that came from Thailand, because same tecnology and ornament model. This route possibility remembering notice by Anderson (2005) this evidence migrations from mainland southeast asia from Vietnam through Penisular Malaysia, entering Sumatera, Kalimantan and Jawa (Simanjuntak,2016:3), and possible of western route migration (Simanjuntak,2016:6) In later period, there was also another migrated group that came to Loyang Mendale, but the group did not come from the same "transitional area" with the previous groups, for example from West Kalimantan (that mean migrations several time). Although they have the same cultural root, which is from southern China or Taiwan, encounter with other groups at the "transitional area" could have created different variations of culture. There is a tendency that cultural areas with several migrated groups from different cultural phases has richer cultural variations compared to isolated areas with only one cultural group. Furthermore, group size, cultural advancement, and time of migration also highly influence the process of admixture with local culture in a cultural area.

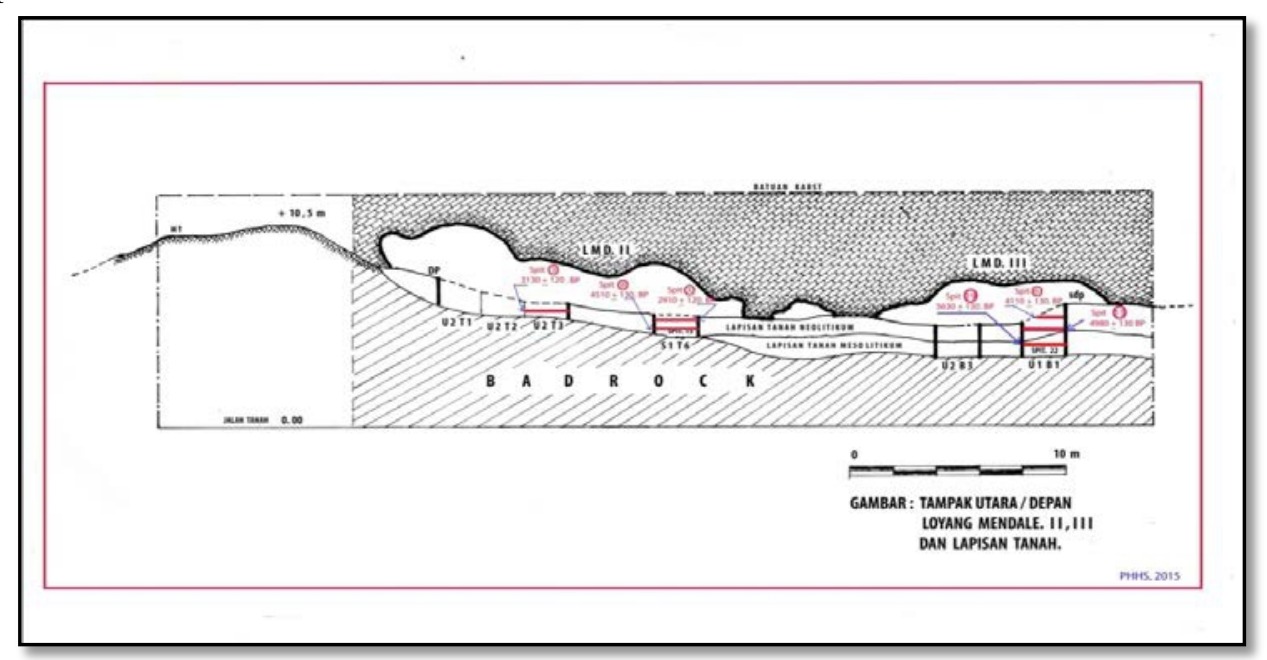

Figure 1.Hoabinhian and Austronesia Layer at Loyang Mendale site 
Based on the above facts, the connection of the cultural root of each site within the same cultural phase will be difficult to identify because the form of culture can differ. Therefore the aspects of Hoabinh cultural item can differ from one site to the other. As for the aspects of cultural items among different cultural phase, they are more difficult to identify. For this reason, similar aspects of cultural items from different cultural phases can be considered a result of mixture, such as flexed burial, polished short axe, and subsistence.

That there were contacts among bearers of different cultures is also proposed by Bellwood (2000:289), who states that the bearers of Post Holocene prehistoric culture in South Sulawesi were Toaleans from Australomelanesoid race, which cultural remains are assumed to be in the topmost layer that dates back from around 4,000 years ago and used Maros points. It assumed that they lived side to side with the Austronesian speakers, who were agriculturalists. In line with it, Heekern (1972) presumed that the topmost layers in Maros and Pangkep - which artifacts include pottery fragments, serrated and winged arrow heads, and bone points - were Toaleans. The arrow heads and bone points are Toalean elements (preAustronesian), while pottery is an Austronesian element. Hence it is thought that there were a mixture of two cultures or two groups from different races lived together in Maros-Pangkep area.

\section{Flexed Burial and Other Religions}

Strong indication that religion has been known during Early Holocene at the Hoabinhian sites along the east coast of Sumatera is evidenced by the discovery of flexed burial at Pangkalan site, which dates back to around 4,860 BP. The flexed burial, with burial gifts, indicates that there has been special treatment for deceased persons. The position of the flexed skeleton resembles the position of a fetus in its mother's womb, which originated from the idea that a dead person will reborn into another world. If the religious meaning is true, then it is apparent that the bearers of Hoabinh culture along the east coast of Sumatera had have a religion, in the sense they believed in life after death. If not, at least they have practiced special treatment for the dead, which presumably was originated from a belief in a certain power inside one's body (soul, spirit).

Apparently early religion is shown by flexed burial with Hoabinhian and Austronesian contexts, for instance a flexed burial at Niah Cave in Serawak (14,000 BP), which is one of the evidences of Austroid/Australomelanesoid evolution. At Gunung Runtuh Cave in Perak, Malaysia was found the skeleton of a male with cacat left arm and hand, buried in squatted position, both knees supporting its chin. This skeleton as the morphology of Australomelanesoid, dates back to about 10,000 years 
ago, and is related to Hoabinh culture (Zuraina1994 in Bellwood 2000:121124;Saidin 2012:17). At Moh Khiew Cave site in the west coast of Southern Thailand was found a human skeleton in flexed position with a rock on top of it, also from the Neolithic period. Such mode of burial is common to the Hoabinhian sites in Vietnam (Pham Huy Thong et al,1980;Nguyen Lan Cuong,1986:11-17 in Pookajorn 1996:329).

In the context of Bacson culture, dated to $6,085 \pm 60 \mathrm{BC}$, in the northern part of di Thanh Hoa Province, Thailand, flexed burials still exist (Bayard 1984 in Higham,:45). If the Bascon is regarded a continuation of the Hoabinh culture, we can say that the bearers were the Australomelanesoids, who have used pottery, just like the bearers of Austronesian culture. So when the Mongoloids came to the northern part of Sumatera (Pangkalan Shell Midden), it is highly possible that both races lived mixed together, which is evidenced not merely by the practice of flexed burial but also the use of pottery.

But if the pottery is associated with the Austronesian culture with the Mongoloids as the bearers, then the flexed burial practice during the Neolithic period was a continuance of the Australomelanesoid (Hoabinh) culture. At the sites of Loyang Mendale and Loyang Ujung Karang there are thirteen whole human skeletons buried in flexed position. The existence of the Australomelanesoid and Mongoloid races in one site with the same type of religion indicates a continuation from the Hoabinhian to the Austronesian. The fact that both races exist at the same site during the same period has led to an interpretation that the bearers of the Austronesian culture had been influenced by the Hoabinh culture.

It seems as though the modes of burying in flexed position or with a rock placed on top of the entire corpse were still practiced during the next period. The Austronesian sites of Loyang Mendale and Loyang Ujung Karang, very clearly show such modes of treatment of the dead. The cultural continuity is also shown by differences of period, culture, and physical characteristics of the human remains. After the two groups of humans were admixed, their cultures developed and led to more complex religion, including the practice of secondary burial using burial container. So it can be assumed that religion had been practiced by pre-Austronesians. During the development of the Austronesian culture, a new religion was born but it still retained some of its old elements. In other words, when a group of Austronesian speakers came to a place that had been occupied by another group of people with different or similar race and culture, they lived together and learned new things from each other while still retained some of their old elements of culture. 


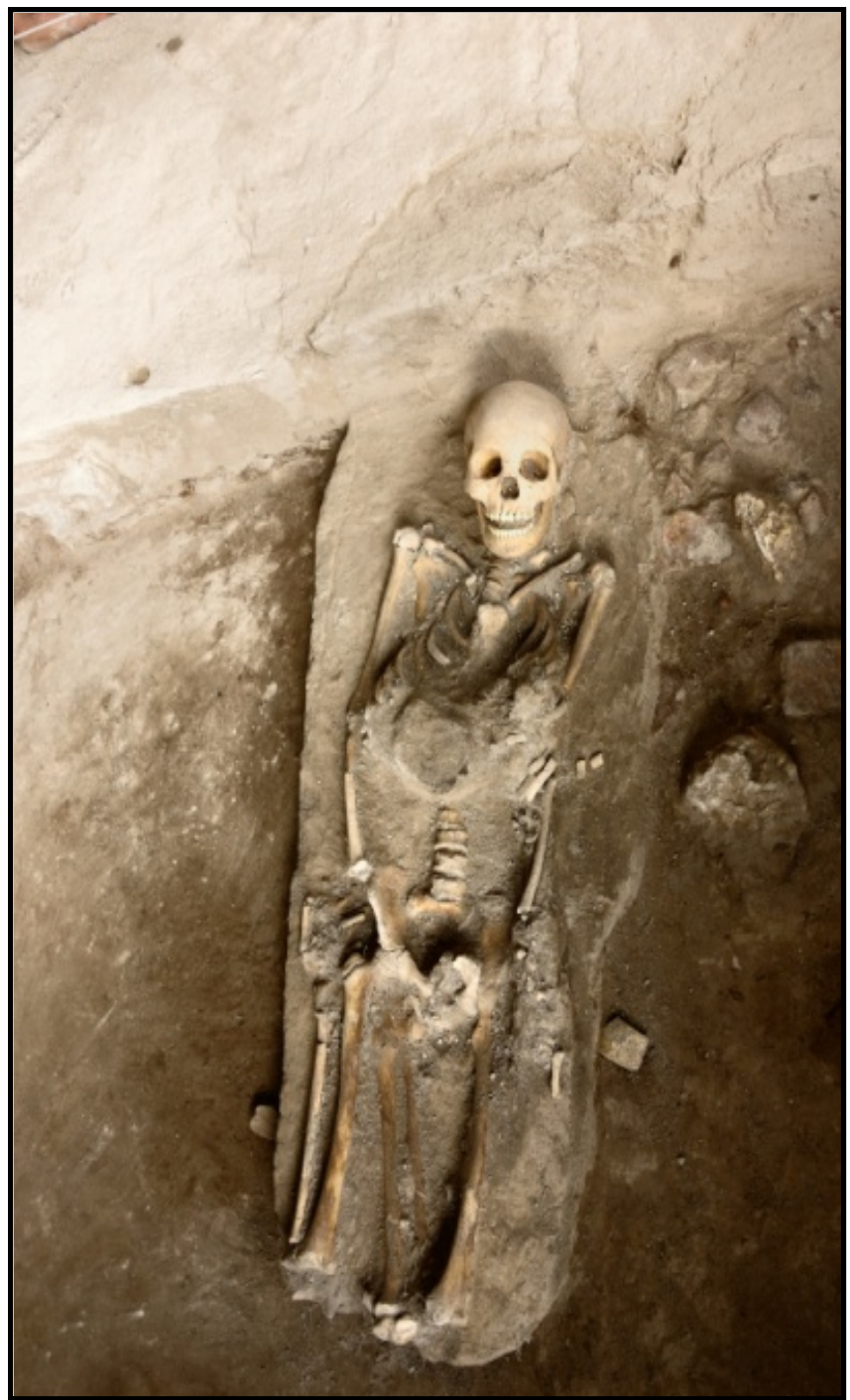

Figure 2. Austronesian Flexed burial culture in Loyang Ujung Karang site, traditions from Hoabinh Culture

The existence of religion since the pre-Austronesia up to the later periods is also shown by the presence of rock art at burial locations with regards to the journey of the spirits of the dead using boats. This cultural element was probably introduced by the bearers of the Dong Son culture who migrated 2,500 years ago (Tanudirjo,2008:25). The rock art is thought to be originated from a much older period than the Neolithic, so that it can be assumed that this element of culture had developed since the preAustronesian until the hegemony period of the Austronesian speakers with their Dong Son culture. The presence of the Dong Son elements of culture in the western part of Indonesia can be seen among the Megalithic of the 
islands of Nias and Samosir. It was the last connecting bridge between the ethnic cultures of West Indonesia and their roots in the prehistoric period.

\section{Lithic Technology}

Archaeologists in Vietnam believe that the Hoabinh culture was followed by the Bacson culture, which dates back to around 11,000 BP. During this period lithic tools with polished tip were known, as well as pottery (mostly plain though some are decorated with impressed rattan/mat motifs), which were widely distributed in at least 6,500 BP and overlapped with the Hoabinh/Bacson cultures at the shell midden site of Da Put in Thanh Hoa Province (Bui Vinh,1991). It seems as though there were a transfer of knowledge on pottery making, and probably also agriculture, to the local in habitants at the end of the Hoabinhian period (Bellwood,2000:242). It can also suggest that there had been cultural contact between the preAustronesians and the Austronesians that led to the transfer of technology, particularly in pottery making.

There is a possibility that transfer of technology also happened at Loyang Ujung Karang site in Aceh Tengah (Central Aceh), as shown by the discovery of two stone axes with similar morphology to short axes but finely polished. The morphology of both types of axes differs from those of rectangular or elongated axes found at the Austronesian sites in general. Short axes were products of the Bacson culture. They are quite short and were steeply flaked at the proximal parts so they look like broken axes. The presence of short axes that were polished like Neolithic axes indicate that the technology of short axe making had been known by the groups of people, which had lived earlier at Loyang Ujung Karang site.

\section{Subsistence}

In the simple social organization of the bearers of the Hoabinh culture, women lived in settlements to take care of their children and wait for the men to come from their hunting trip. Hunting trips can take quite a long time, and there is an indication that the women in the settlement collected edible plants from the surrounding environment or even practiced simple domestication.

The agricultural activities during the Holocene period are evidenced by results of pollen analysis. At Pangkalan shell midden in Eastern Aceh were found pollens of Leguminosae (types of peas) and Rubiaceae (types of coffee) from 10,240 \pm 250 BP (Wiradnyana,2011:28-118). Bellwood (2000:301) states that once in a while groups of hunter and gatherer, such as the bearers of the Hoabinh culture, had probably protected or even planted wild tubers or fruit trees in simple ways before systematic agriculture was known. In line with that, Hall (1960) also mentioned that food can also be 
acquired by planting vegetables or legumes around the habitation places. It was done by women, while men usually hunt or catch fish as well as collect food (Hall,1960:6). Gorman (1977), in his carpology and pollen analyses at Spirit Cave (Thailand) supports that there were early agriculture, aside from finding the oldest date for pottery, which is 10,000 BP (Forestier, 2007:48), while Soejono and Leirissa (2007:182) mentioned result of radio-carbon dating on rice grain and husk that were associated with pottery from Ulu Leang 1 Cave at Maros, South Sulawesi, which is around 2,160-1,700 BC. Dating in Malawa Site, Bulu Bakung, South Sulawesi from two samples of charcoal i.e. $3,580 \pm 130 \mathrm{BP}$ and 2,710 $\pm 170 \mathrm{BP}$ (P3G-06) calibrated to 4,248-3,556 BP and 3,242-2,358 BP respectively (CALIB version 6.0 at two sigma range) ( Simanjuntak,2008:233). In Minangga Sipakko, South Sulawesi from the pottery and on clay analysis are cover three period of human settlement at 3,500-3,000 BP (Simanjuntak, 1994-5; 2006:226)

The existence of hunter and gatherer groups, particularly the bearers of the Hoabinh culture, which had have the ability to increase food resources, seemed to have no problem in later period, the Neolithic, with the coming of the Austronesian speakers. The cultural contact between the Hoabinhian and Austronesian groups enabled the concept brought by the Austronesian speakers to be used by the bearers of the Hoabinh culture and vice-versa. The Austronesian speakers are believed to master a systematic agricultural technology to grow various edible plants known to the Australomelanesoids, and the kinds of plants were gradually developed into Leguminosae (legumes like peas), Papilionaceae (nuts), Rubiaceae (coffee) and Convolvulaceae (morning glory). The pland diversification occurred in around 3,870 \pm 140

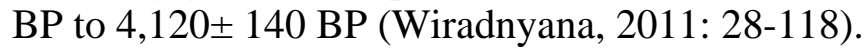

\section{Conclusion}

The existenceAustralomelanesoids with Hoabinh culture in the western part of Indonesia is a strong indication that pluralism has entered this area. The coming of the Mongoloids with Austronesian culture has made it even more so. Interracial mixtures that happened in Asia, including at the Hoabinhian sites in West Indonesia, which can be seen by the presence of Austronesian elements of culture at those sites, indicates that the groups of people used the same area both during the same period or at different times. It is evidenced by the same dating for their activities. Similarities of cultural elements such as subsistence, religion, and technology among the Australomelanesoids with Austronesian culture show that there was Hoabinhian influence in the Austronesian culture. The later period, which is the Megalithic, seemed to enrich the local culture, and the tradition continues until nowadays. It proves that diversity in the western part of Indonesia has been practiced since the prehistoric period. 


\section{Acknowledgment:}

I would like to thank Prof. Ris.Dr. Truman Simanjuntak for the corrections.

\section{References:}

1. Bellwood, Peter. (2000) Prasejarah Kepulauan IndoMalaysia.Jakarta: P.T. Gramedia Pustaka Utama.

2. Boedhisampurna, S. (1983) "Kerangka Manusia dari Bukit Kelambai, Stabat, Sumatera Utara”. dalam PIA III. Jakarta: Puslit Arkenas

3. Budisantosa, Tri Marhaeni. (2011) "Megalit dan Kubur Tempayan Dataran Tinggi Jambi: Situs Lolo Gedang, Kerinci” in Asia Tenggara dalam Persepektif Arkeologi. Palembang: Balar Palembang

4. Forestier, Hubert. (2007) Ribuan Gunung Ribuan Alat Batu, Prasejarah Song Keplek, Gunung Sewu, Jawa Timur. Jakarta: KPG

5. Hall, D.G. (1960) A History of South-East Asia.London:Macmillan \& Co.LTD

6. Heekern,H.R.van. (1972). The Stones Age of Indonesia. The Hague: Martnus Nijhoff

7. Higham, Charles. (No year) The Archaeology of Mainland Southeast Asia. Cambridge: Cambridge University Press

8. Pookajorn, Surin. (1996) " Final Report of Excavations at Moh. Khiew Cave, Krabi Province: Sakai Cave Trang Province and Ethnoarchaeological Research of Hunter-gatherer Group,Socall Mani or Sakai or Orang Asli at Trang Province” inThe Hoabinh Research Project in Thailand. Bangkok: Department of Archaeology, Faculty of Archaeology, Silpakorn University

9. Saidin, Mokhtar. (2012) From Stone Age to Early Civilisation in Malaysia. Pulau Pinang: Universiti Sains Malaysia

10. Simanjuntak, Truman. (1994-5) "Kalumpang: Hunian Sungai Bercorak Neolitik -Paleometalik di Pedalaman Sulaesi Selatan”. dalam Aspek-Aspek Arkeologi Indonesia No.17.

11. Simanjuntak, Truman. (2006) "Advancement of Research on the Austronesian in Sulawesi”. In Truman Simanjuntak, M. Hisyam, Bagyo Prasetyo, Titi Surti Nastiti (eds). Archaeology: Indonesian Perspective R.P. Soejono”s Festschrift. Jakarta:LIPI Press: 223-231

12. Simanjuntak, Truman. (2008) “Austronesian in Sulawesi: its Origin, Diaspora and Living Traditions”. In Truman Simanjuntak (ed). Austronesian in Sulawesi.Depok:Centre for Prehistoric and Austronesian Studies:215-251

13. Simanjuntak, Truman. (20016) The Western Route Migrations: A Second Probabli Neolithic Diffusion To Indonesia. Peter Bellwood Festschrift. Terra Australia (in process publish) 
14. Soegondho, Santoso. (2008) "Prasejarah Maluku: Mata Rantai Budaya Asia-Pasifik" inPrasejarah Indonesia in Lintasan Asia Tenggara-Pasifik. Yogyakarta: Asosiasi Prehistorisi Indonesia

15. Soejono, RP \& Leirissa, RZ. (2007) Sejarah Nasional Indonesia I, Zaman Prasejarah di Indonesia (edisi pemutakhiran). Jakarta: Balai Pustaka

16. Tanudirjo, Daud A. (2008) "Problem dan Prospek Kajian Seni Cadas Prasejarah di Indonesia” inPrasejarah Indonesia dalam Lintasan Asia Tenggara-Pasifik. Yogyakarta: Asosiasi Prehitorisi Indonesia

17. Wiradnyana, Ketut. (2010) Legitimasi Kekuasaan pada Budaya Nias. Jakarta: Yayasan Pustaka Obor Indonesia

18. Wiradnyana, Ketut. (2011) Prasejarah Sumatera Bagian Utara Kontribusinya pada Kebudayaan Kini. Jakarta: Yayasan Obor Indonesia

19. Wiradnyana, K. \& Taufiqurahman S. (2011) Gayo Marangkai Identitas. Jakarta: Yayasan Obor Indonesia

20. Wiradnyana, Ketut. (2012) ”Indikasi Pembauran Budaya Hoabinh dan Austronesia di Pulau Sumatera Bagian Utara”,in Berkala Arkeologi Sangkhakala Vol XV No.1 Mei 2012.Medan: Balar Medan.

21. Wiradnyana, Ketut. et al. (2015) Laporan Hasil Penelitian. Austronesia di Indonesia Bagian Barat (Kajian Budaya Austronesia Prasejarah dan Sesudahnya di Wilayah Budaya Gayo). Medan: Balar Medan (unpublished) 